\title{
A Simplified Method for Sample Collection and DNA Isolation for Polymerase Chain Reaction Detection of Trypanosoma rangeli and Trypanosoma cruzi in Triatomine Vectors
}

\author{
Evandro MM Machado, Nelson J Alvarenga, Alvaro J Romanha*, \\ Edmundo C Grisard ${ }^{* *}+$
}

\begin{abstract}
Laboratório de Triatomíneos e Epidemiologia da Doença de Chagas *Laboratório de Parasitologia Celular e Molecular, Centro de Pesquisas René Rachou-Fiocruz, Belo Horizonte, MG, Brasil **Departamento de Microbiologia e Parasitologia, Universidade Federal de Santa Catarina, Caixa Postal 476, 88040-900
\end{abstract}

Florianópolis, SC, Brasil

\begin{abstract}
Due to the overlapping distribution of Trypanosoma rangeli and T. cruzi in Central and South America, sharing several reservoirs and triatomine vectors, we herein describe a simple method to collect triatomine feces and hemolymph in filter paper for further detection and specific characterization of these two trypanosomes. Experimentally infected triatomines feces and hemolymph were collected in filter paper and specific detection of $\mathrm{T}$. rangeli or $\mathrm{T}$. cruzi DNA by polymerase chain reaction was achieved. This simple DNA collection method allows sample collection in the field and further specific trypanosome detection and characterization in the laboratory.
\end{abstract}

Key words: Trypanosoma cruzi - Trypanosoma rangeli - polymerase chain reaction - triatomines Dipetalogaster maximus

Trypanosoma cruzi Chagas (1909), the etiological agent of Chagas disease, affects more than 18 million people in America. Among distinct ways, T. cruzi is mainly transmitted by triatomine bug feces containing metacyclic trypomastigote forms of the parasite (WHO 1991). Trypanosoma rangeli Tejera (1920) infects several mammalian species including man in Central and South America. T. rangeli presents an overlapping distribution with $T$. cruzi, sharing animal reservoirs and triatomine vectors. Differently from $T$. cruzi, $T$. rangeli is considered pathogenic only for the triatomine bugs, being harmless to the vertebrate hosts. However, $T$. rangeli induces a humoral immune response in humans that strongly cross-reacts with $T$. cruzi (Grisard et al. 1999b). The sympatric distribution,

\footnotetext{
Financial support: Capes (Brazilian Government Agency) and Fiocruz

${ }^{+}$Corresponding author. Fax: +55-48-331.9258. E-mail: grisard@ccb.ufsc.br

Received 27 January 2000

Accepted 19 June 2000
}

allowing the occurrence of single and/or mixed infections in both vertebrate and invertebrate hosts, allied to the cross-reactivity in serological assays are of great importance for Chagas disease diagnosis, specially in the indeterminate form of the chronic phase (D'Alessandro \& Saravia 1992).

Detection of $T$. rangeli and $T$. cruzi infections are based on the same serological and parasitological assays such as indirect immunofluorescence, enzyme linked immunosorbend assay, hemoculture and xenodiagnosis. However, none of these methods can specifically detect these trypanosomes. Recently, some authors have used molecular assays in order to specifically detect $T$. rangeli and $T$. cruzi in vertebrate and invertebrate hosts using distinct DNA extraction methods (Moser et al. 1989, Brenière et al. 1995, Russomando et al. 1996, Shikanai-Yasuda et al. 1996, Souto et al. 1999, Vallejo et al. 1999).

We now report here a polymerase chain reaction (PCR) for specific detection of T. rangeli and T. cruzi DNA in feces and hemolymph of the experimentally infected triatomine (Dipetalogaster maximus), using a simple method for sample collection and DNA isolation.

The $T$. cruzi CL strain, isolated from Triatoma infestans in Brazil (Brener \& Chiari 1963) and $T$. 
rangeli SC-58 strain isolated from the naturally infected rodent Echimys dasythrix in Southern Brazil (Steindel et al. 1991) were used. These strains were respectively maintained in liver infusion tryptose (LIT) and in NNN+LIT medium at $26^{\circ} \mathrm{C}$ by weekly passages.

Fourth stage nymphs of D. maximus were used in this study. They were obtained from the Laboratório de Triatomíneos e Epidemiologia da Doença de Chagas, Centro de Pesquisas René Rachou-Fiocruz. Three groups of 30 triatomines were independently fed with LIT medium and with exponential growth phase cultures of $T$. rangeli and T. cruzi in artificial feeders. After the infective meal, triatomines were kept at $27^{\circ} \mathrm{C}, 70 \%$ humidity and fed on mice each 15 days. Hemolymph was obtained from each triatomine by section of a single leg. Daily observations for the presence of flagellates in feces and hemolymph of all triatomines were performed after ten days post feeding under light microscopy by both fresh and Giemsa stained smears. Also, feces and hemolymph were collected every ten days after the infective meal in sterile filter papers, air dried and stored at $-20^{\circ} \mathrm{C}$ until use. Feces and hemolymph of all non-infected triatomines fed on LIT medium were also collected as PCR control.

Prior PCR analysis, $50 \mu \mathrm{l} \mathrm{FPLC} \mathrm{pure} \mathrm{water} \mathrm{was}$ added to round filter paper pieces of $6 \mathrm{~mm}$ in diameter containing feces and hemolymph and boiled in eppendorf microtubes for $10 \mathrm{~min}$. After cooling at room temperature and a short spin at $14,000 \mathrm{x} \mathrm{g}$, $2 \mu \mathrm{l}$ of the supernatant was directly applied to the PCR reaction. PCR for specific $T$. rangeli detection was performed according to Grisard et al. (1999a) using primers TrINT-1/2 and TrINT-3/2 that are directed to the mini-exon gene. For specific T. cruzi detection, PCR was performed according to Diaz et al. (1992) using primers Diaz-7/ Diaz-8 directed to a repetitive nuclear DNA sequence. Amplification products were resolved in polyacrylamide gel electrophoresis and revealed after silver staining (Santos et al. 1993).

After 15 and 21 days of infection, microscopic observation of feces and hemolymph of $T$. rangeli infected triatomines revealed the presence of parasites, respectively. For $T$. cruzi infected triatomines, parasites were detected in feces by microscopy after 15 days of the infective meal. Our results showed a complete agreement between the microscopic observation of $T$. cruzi in feces and $T$. rangeli in feces and hemolymph and the PCR detection up to 60 days after infection (Fig. 1a).

PCR detection of $T$. rangeli DNA in hemolymph and feces of infected triatomines was possible with both primer pairs up to 110 days after infection. The presence of the amplification products obtained with primers TrINT-1/2 and TrINT$3 / 2$ was observed even when no parasites were detected by microscopy. Since TrINT-1/2 and TrINT-3/2 primers revealed the same results, the amplification products obtained with primers TrINT-3/2 are shown in Fig. 1a. The origin of the fragment of approximately $194 \mathrm{bp}$ is under study, but it is still unknown. It is a $T$. rangeli strain dependent phenomenon and appears to indicate that different strains may have distinct arrangement types of the mini-exon gene (Grisard, pers. commun.).

As observed for $T$. rangeli, PCR reaction revealed the $195 \mathrm{bp}$ amplification product (Fig. 1b) in all T. cruzi samples from 15 up to 110 days after the infective meal. As already described, we observed no PCR cross-reaction when using the specific primers and DNA from T. cruzi and T. rangeli (Diaz et al. 1992, Grisard et al. 1999a). Also, no reaction was observed when using both specific primers and DNA from non-infected triatomine feces and hemolymph (Figs 1a, 1b). Positive feces of both $T$. rangeli and $T$. cruzi-infected triatomines were mixed and used as DNA source for PCR, revealing no cross-reaction (data not shown). Our results are in agreement with Diaz et al. (1992) and Grisard et al. (1999a) descriptions, where no crossreaction between $T$. cruzi and $T$. rangeli DNA was observed.

Our results confirm the feasibility of the PCR technique to detect single or mixed infections by $T$. rangeli and $T$. cruzi in triatomine vectors using a simple technique to collect samples and extract DNA for PCR. Formerly, the triatomine feces were collected in filter paper for the precipitin assays in order to identify their blood source. Using the same approach, triatomine feces and hemolymph collected in filter paper allowed us to specifically detect DNA of the two trypanosomes species infecting humans in Central and South America. This method proved to be easy, fast, effective, sensitive, low cost and reproducible, being of great importance for field works with triatomines, specially in areas where $T$. rangeli and $T$. cruzi coexist. Moreover, this method allows further strain typing by different molecular methods such as ramdomly amplified polymorphic DNA (Steindel et al. 1994), LSSP-PCR (Pena et al. 1994) or PCR amplification of specific genes such as the miniexon (Grisard et al. 1999a).

In natural conditions, D. maximus is not a $T$. rangeli vector. This triatomine species has the ability to abort hemolymph infections by killing the parasite. Thus, our positive PCR results at 110 days after the infective meal did not mean active infec- 
tion, but the presence of the parasite DNA. Other studies will be carried out with natural $T$. rangeli vectors which can longer sustain the parasite in the hemolymph. Due to the $T$. rangeli importance in the epidemiology of Chagas disease, the methodology proposed here may be of the outmost importance to study the $T$. rangeli distribution, allowing a simple sample collection and DNA isolation that can be used to detect single or mixed natural triatomine infections.
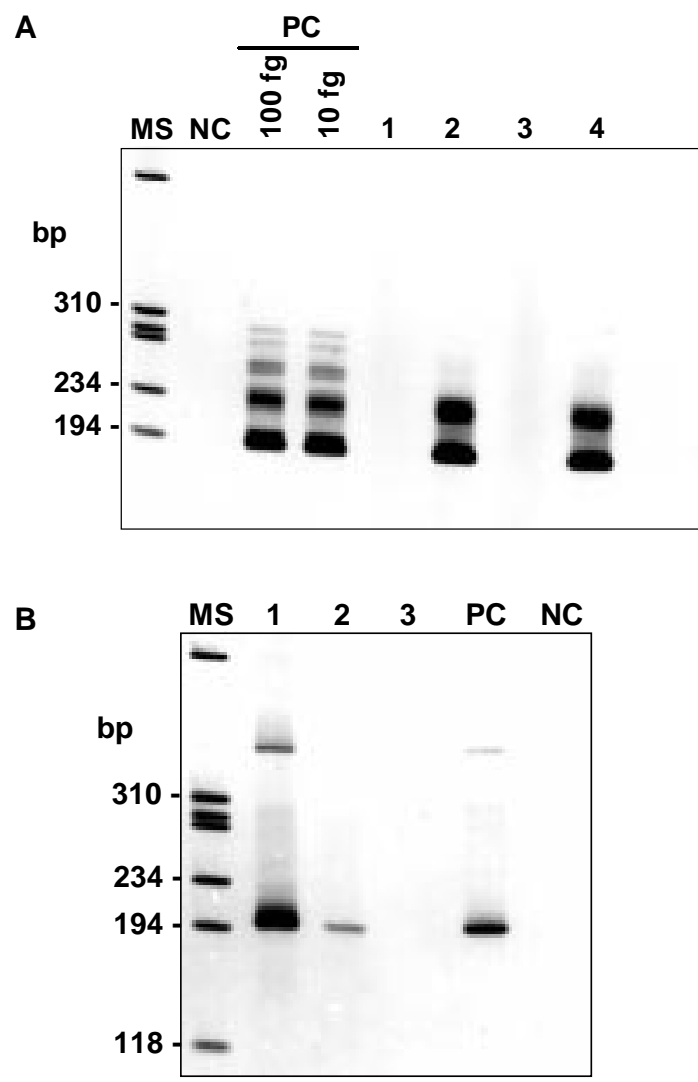

Fig. 1 - A: polymerase chain reaction (PCR) amplification of feces and hemolymph of Dipetalogaster maximus, experimentally infected with Trypanosoma rangeli SC-58 strain using primers TrINT-3/2. Samples were taken 60 days after the infective meal. PC: positive controls: 100 and $10 \mathrm{fg}$ of total DNA from $T$. rangeli Choachi strain. Lanes 1 and 3 are feces and hemolymph of the non-infected triatomine group. Based on light microscopy, lanes 2 and 4 are positive feces and hemolymph, respectively; B: PCR amplification of feces and hemolymph of $D$. maximus, experimentally infected with $T$. cruzi CL strain using primers Diaz-7/8 at different days after the infective meal. 1: feces collected at 15 days; 2 : at 110 days after infection; 3: feces from non-infected triatomines; PC: positive control: $100 \mathrm{fg}$ of $T$. cruzi total DNA. MS: molecular size marker ( $\phi \mathrm{x} 174 \mathrm{Hae}$ III digested); NC: negative control (no DNA added); gels are 6\% polyacrylamide gel, silver stained.

\section{REFERENCES}

Brener Z, Chiari E 1963. Variações morfológicas observadas em diferentes amostras de Trypanosoma cruzi. Rev Inst Med Trop São Paulo 5: 220-224.

Brenière SF, Bosseno MF, Telleria J, Carrasco R, Vargas F, Yaksic N, Noireau F 1995. Field application of polymerase chain reaction diagnosis and strain typing of Trypanosoma cruzi in Bolivian triatomines. Am J Trop Med Hyg 53: 179-184.

D’Alessandro A, Saravia NG 1992. Trypanosoma rangeli. In JP Kreier, JP Barker (eds), Parasitic Protozoa, 2nd ed., Academic Press Inc., San Diego, p. $1-54$.

Diaz C, Nussenzweig V, Gonzales A 1992. An improved polymerase chain reaction assay to detect Trypanosoma cruzi in blood. Am J Trop Med Hyg 46: 616623.

Grisard EC, Campbell DA, Romanha AJ 1999a. Miniexon gene sequence polymorphism among Trypanosoma rangeli strains isolated from distinct geographical regions. Parasitology 118: 375-382.

Grisard EC, Steindel M, Guarneri AA, Eger-Mangrich I, Campbell DA, Romanha AJ 1999b. Characterization of Trypanosoma rangeli strains isolated in Central and South America: an overview. Mem Inst Oswaldo Cruz 94: 203-209.

Moser DR, Kirchhoff LV, Donelson JE 1989. Detection of Trypanosoma cruzi by DNA amplification using the polymerase chain reaction. J Clin Microbiol 27: 1477-1482.

Pena SDJ, Barreto G, Vago AR, Marco LD, Reinach FC, Dias Neto E, Simpson AJG 1994. Sequencespecific "gene signatures" can be obtained by PCR with single specific primers at low stringency. Proc Natl Acad Sci USA 91: 1946-1949.

Russomando G, Rojas de Arias A, Almiron M, Figueiredo A, Ferreira ME, Morita K 1996. Trypanosoma cruzi: PCR - based detection in dried feces of Triatoma infestans. Exp Parasitol 83: 62-66.

Santos FR, Pena SDJ, Epplen JT 1993. Genetic and population study of an Y-linked tetranucleotide repeat DNA polymorphism. Human Genetics 90 : 655656.

Shikanai-Yasuda MA, Ochs DE, Tolezano JE, Kirchhoff LV 1996. Use of PCR for detecting Trypanosoma cruzi in triatomine vectors. Trans $R$ Soc Trop Med Hyg 90: 649-651.

Souto RP, Vargas N, Zingales, B 1999. Trypanosoma rangeli: discrimination from Trypanosoma cruzi based on a variable domain from the large subunit ribosomal RNA gene. Exp Parasitol 91: 306-314.

Steindel M, Carvalho Pinto CJ, Toma HK, Mangia RHR, Ribeiro-Rodrigues R, Romanha AJ 1991. Trypanosoma rangeli (Tejera, 1920) isolated from a sylvatic rodent (Echimys dasythrix) in Santa Catarina Island, Santa Catarina State: first report of this trypanosome in Southern Brazil. Mem Inst Oswaldo Cruz 86: 7379.

Steindel M, Dias Neto E, Ribeiro-Rodrigues R, Carvalho Pinto CJ, Grisard EC, Menezes CLP, Murta SMF, Simpson AJG, Romanha AJ 1994. Randomly am- 
plified polymorphic DNA (RAPD) and isoenzyme analysis of Trypanosoma rangeli strains. J Euk Microbiol 41: 261-267.

Vallejo GA, Guhl F, Chiari E, Macedo AM 1999. Species specific detection of Trypanosoma cruzi and Trypanosoma rangeli in vector and mammalian hosts by polymerase chain reaction amplification of kinetoplast minicircle DNA. Acta Trop 72: 203212.

WHO - World Health Organization 1991. Control of Chagas Disease, WHO Technical Report Series 811, Geneva, 95 pp. 